\title{
Biologi dan kelimpahan tungau merah Tetranychus sp. (Acari: Tetranychidae) pada dua kultivar jarak pagar (Jatropha curcas)
}

\author{
Biology and abundance of spider mite Tetranychus sp. \\ (Acari: Tetranychidae) on two Jatropha curcas cultivars
Sugeng Santoso ${ }^{1 *}$, Aunu Rauf ${ }^{1}$, Nelly Mastina Gultom ${ }^{1}$, EIna Karmawati ${ }^{2}$, Widi Rumini ${ }^{2}$ \\ ${ }^{1}$ Departemen Proteksi Tanaman, Fakultas Pertanian, Institut Pertanian Bogor \\ Jalan Kamper, Kampus IPB Darmaga, Bogor 16680 \\ ${ }^{2}$ Balai Penelitian Tanaman Industri, Badan Penelitian dan Pengembangan Pertanian \\ Jalan Tentara Pelajar, Cimanggu, Bogor 16111 \\ (diterima Januari 2013, disetujui Juni 2013)
}

\begin{abstract}
ABSTRAK
Tungau merah Tetranychus sp. merupakan salah satu hama penting yang menyerang daun jarak pagar (Jatropha curcas). Penelitian ini bertujuan untuk mengetahui masa perkembangan, parameter neraca hayati dan kelimpahan tungau merah Tetranychus sp. pada dua kultivar jarak pagar. Pengamatan lapangan dilaksanakan di kebun jarak pagar Balai Penelitian Tanaman Industri (BALITTRI), Sukabumi, sedangkan penelitian laboratorium dilaksanakan di Departemen Proteksi Tanaman, Fakultas Pertanian, Institut Pertanian Bogor. Hasil penelitian menunjukkan bahwa kultivar jarak pagar berpengaruh nyata terhadap beberapa parameter neraca kehidupan Tetranychus sp. Tetranychus sp. yang dipelihara pada kultivar IP1-P-P mempunyai masa oviposisi yang lebih panjang dan keperidian yang lebih tinggi (7,00 hari dan 25,56 telur) dibandingkan pada IP2-P-P (5,00 hari dan 10,00 telur). Nisbah kelamin Tetranychus sp. 3,2:1 pada IP1-P-P dan 2,5:1 pada IP2-P-P. Laju pertumbuhan intrinsik Tetranychus sp. juga lebih tinggi pada kultivar IP1-P. Namun demikian, pengamatan di lapangan menunjukkan bahwa kelimpahan Tetranychus sp. pada kultivar IP1-P-P, lebih rendah dibandingkan dengan IP2-P-P. Hal ini diduga berkaitan dengan keberadaan arthropoda lain pada kultivar IP1-P-P. Secara umum populasi tertinggi Tetranychus sp. terjadi pada bulan Agustus dan terendah pada bulan Oktober-November. Tungau predator Famili Phytoseiidae ditemukan berasosiasi dengan tungau merah, tetapi kurang memiliki peran aktif sebagai pengendali alamiah.
\end{abstract}

Kata kunci: jarak pagar, tungau merah, tungau predator

\begin{abstract}
Red spider mite Tetranychus sp. is one of the most important pests attacking leaves of Jatropha curcas. The objective of this study was to elucidate life history parameters and abundance of spider mite on two $J$. curcas cultivars. Field studies were carried out in BALITTRI Pakuwon Sukabumi, and laboratory experiments were conducted at the Department of Plant Protection, Bogor Agricultural University, from June to November 2008. Cultivars significantly affected several life history parameters of the spider mite. Spider mite reared on IP1-P cultivar have longer oviposition period and higher fecundity than those on IP2-P (7.00 days and 25.56 eggs against 5.00 days and
\end{abstract}

\footnotetext{
*Penulis korespondensi: Sugeng Santoso. Departemen Proteksi Tanaman, Fakultas Pertanian, Institut Pertanian Bogor, 
10.00 eggs). The sex ratio of spider mite was $3.2: 1$ on IP1-P and $2.5: 1$ on IP2-P. Intrinsic rate of increase was also higher on IP1-P. However, field studies indicated that the spider mite were less abundant on this cultivar. These might be due to the presence of other arthropods which were higher on IP1-P. In general, the highest population of spider mite occurred in August and the lowest in October-November. Predatory mite Family Phytoseiidae was found associated with spider mite, however its role as natural control agent was not significant.

Key words: Jatropha curcas, predatory mite, spider mite

\section{PENDAHULUAN}

Indonesia memiliki 60 tumbuhan yang dapat menghasilkan bahan bakar minyak, namun hanya empat tanaman yang lebih diprioritaskan, yaitu kelapa sawit, tebu, singkong, dan jarak pagar (Prihandana et al. 2007). Dari keempat tanaman tersebut, jarak pagar paling potensial untuk dikembangkan sebagai bahan baku biodisel karena minyaknya tidak dapat dimakan sehingga semuanya dimanfaatkan untuk bahan bakar, sedangkan minyak dari kelapa sawit, tebu, dan singkong masih dapat digunakan sebagai bahan pangan/minyak makan untuk kebutuhan sehari-hari (Prihandana et al. 2007). Jarak pagar merupakan jenis tanaman semak atau pohon yang tahan terhadap kekeringan, sehingga tahan hidup di daerah dengan curah hujan rendah. Tanaman ini banyak ditemukan di Afrika Selatan, Afrika Tengah, India Selatan dan Asia Tenggara (Hamdi 2007). Tanaman jarak pagar menghasilkan biji yang mempunyai kandungan minyak cukup tinggi, yaitu mencapai 35-45\% (Hambali et al. 2006). Komoditas ini juga sangat potensial karena dapat ditanam di lahan-lahan marjinal dan lahan kritis. Pengembangan perkebunan jarak pagar dalam skala besar di Indonesia cocok dilakukan di wilayah Indonesia Timur, terutama NTB, NTT, Sulawesi Tenggara, Gorontalo, Maluku dan Papua (Hambali et al. 2006). Beberapa kultivar unggulan jarak sudah dikembangkan, diantaranya IP1Asembagus (IP1-A) dan IP2-Asembagus (IP2A) untuk wilayah kering dataran rendah. Kultivar unggulan lain adalah IP1-Muktiharjo (IP1-M) dan IP2-Muktiharjo (IP2-M) untuk wilayah iklim sedang dataran sedang serta IP1-Pakuwon (IP1-P) dan IP2-Pakuwon (IP2-P) untuk wilayah iklim basah dataran tinggi.

Salah satu yang menjadi masalah dalam pengusahaan jarak pagar adalah adanya serangan hama. Hambali et al. (2006) melaporkan berbagai spesies serangga dan organisme lainnya yang menjadi hama pada tanaman jarak pagar, diantaranya ulat tanah, lundi, belalang, ulat grayak, penggerek batang, ulat api, wereng daun, kepik hijau, penggerek pucuk dan tungau. Sementara itu, dari hasil survei yang dilakukan di Jawa Tengah dan Jawa Timur, ditemukan 3 famili tungau yang menyerang tanaman jarak pagar, yaitu famili Tarsonemidae, Eriophyidae, dan Tetranychidae. Berdasarkan tingkat serangannya di lapangan, tungau-tungau ini sudah dapat digolongkan dalam kategori hama penting pada tanaman jarak pagar, karena tingkat serangannya melebihi $90 \%$ (Asbani et al. 2007). Dari hasil survei di tempat lain, Rumini \& Karmawati (2007) juga melaporkan bahwa diantara berbagai jenis hama yang ditemukan menyerang pertanaman jarak pagar terdapat tungau famili Tarsonemidae dan Eriophyidae.

Tetranychidae, salah satu tungau yang menyerang jarak pagar yang termasuk famili terbesar sebagai fitopag (Deciyanto et al. 1991). Tetranychus (Acari: Tetranychidae) adalah tungau pengisap daun yang menjadi hama pada sebagian besar komoditas pertanian. Tungau ini memintal sarang jaring yang halus di sekeliling daun sebagai tempat untuk menambatkan telur dan juga sebagai pelindung agar koloni tungau ini dapat makan tanpa terganggu (Deciyanto et al. 1991). Tetranychus sp. menyerang daun-daun muda maupun yang tua (relatif tua) dengan cara menghisap cairan pada jaringan epidermis daun sehingga timbul bercakbercak putih, semakin banyak dan daun menjadi kuning selain itu mengakibatkan daun berlekuk tidak teratur, pada serangan berat daun menjadi rontok (Asbani et al. 2007). Serangan tungau seringkali tidak dikenali karena ukuran tubuhnya yang sangat kecil dan hidup tersembunyi dan serangan baru dapat diketahui setelah daun berubah warna menjadi putih kecoklat-coklatan (Deciyanto et al. 1989). Berdasarkan pengalaman di lapangan tungau dapat menyebabkan kerusakan pada daun 
hampir 90\%. Serangan tungau di lapangan pada musim hujan bisa mencapai $40 \%$, sedangkan pada musim kemarau dapat lebih tinggi. Tungau adalah hama yang paling berbahaya pada masa vegetatif karena dapat membawa virus dan serangannya menjadi lebih berat (Karmawati 2006). Sampai saat ini belum ada penelitian tentang biologi dan kelimpahan populasi tungau merah, serta musuh alaminya pada tanaman jarak pagar. Oleh karena itu, penelitian ini mempunyai arti sangat penting untuk melengkapi berbagai informasi yang ada yang bisa digunakan dalam penyusunan strategi pengendalian tungau pada tanaman jarak pagar.

Penelitian ini bertujuan untuk mengetahui masa perkembangan, parameter neraca hayati dan kelimpahan tungau merah Tetranychus sp. pada dua kultivar jarak pagar.

\section{BAHAN DAN METODE}

\section{Waktu dan tempat}

Penelitian dilaksanakan di Laboratorium Ekologi Serangga, Departemen Proteksi Tanaman, Fakultas Pertanian, Institut Pertanian Bogor dan di Kebun Jarak Pagar, Balai Penelitian Tanaman Industri (BALITTRI) Pakuwon, Sukabumi sejak bulan Juni 2008 sampai November 2008

\section{Biologi tungau merah pada tanaman jarak pagar kultivar IP1-P dan IP2-P}

Arena pemeliharaan adalah cawan petri $(\varnothing=$ $6 \mathrm{~cm}$ ), yang di dalamnya secara berurutan diletakkan busa $(\varnothing=5,5 \mathrm{~cm})$, kapas $(5 \mathrm{~cm} \times 4$ $\mathrm{cm})$, dan daun jarak pagar yang bebas pestisida. Busa dan kapas selalu dijenuhi dengan air untuk menjaga kesegaran daun jarak pagar dan mencegah tungau keluar dari arena percobaan. Tungau diperoleh dari kebun jarak di Pakuwon Sukabumi. Tungau dipelihara dan dikembangbiakkan pada arena pemeliharaan. Kultivar jarak pagar yang digunakan adalah IP1-P dan IP2-P.

Lima puluh imago tungau merah betina ditempatkan pada arena percobaan dan dibiarkan selama dua jam agar meletakkan telur. Telur yang diletakkan dibuang dengan menyisakan satu butir telur per arena percobaan (50 telur untuk masing-masing kultivar). Telur diamati setiap enam jam sampai menetas dan menjadi imago. Lama perkembangan dari setiap stadia dicatat. Keberadaan eksuvia pada daun digunakan sebagai tanda ganti kulit. Setelah menjadi imago, nisbah kelamin, masa praoviposisi, oviposisi, pascaoviposisi, keperidian, serta lama hidup imago diamati dan dicatat.

\section{Kelimpahan tungau merah dan tungau predator pada pertanaman jarak pagar kultivar IP1-P dan IP2-P}

Pengamatan kelimpahan populasi tungau merah dan tungau predator pada dua kultivar jarak pagar dilakukan setiap 10 hari sekali. Pengamatan dilakukan terhadap 50 tanaman contoh yang sama untuk masing-masing kultivar. Dari setiap tanaman contoh diambil masing-masing satu daun pucuk, sedang dan tua. Daun contoh dimasukkan ke dalam kantong plastik, ditempatkan di dalam kotak pendingin (ice box) dan dibawa ke laboratorium untuk diamati. Pengamatan dilakukan dengan mikroskop stereo standar penelitian. Jumlah semua stadia tungau merah serta tungau predator dihitung. Sebagai data tambahan hama-hama dan musuh alami lain yang ditemukan juga dihitung.

\section{HASIL}

\section{Biologi tungau merah pada tanaman jarak pagar kultivar IP1-P dan IP2-P}

Selama masa hidupnya Tetranychus sp. melewati empat stadia utama, sampai menjadi dewasa, yaitu telur, larva, protonimfa, dan deutonimfa. Di antara stadia larva dan protonimfa terdapat fase istirahat yang disebut dengan protochrysalis, sedangkan di antara stadia protonimfa dan deutonimfa terdapat fase istirahat yang disebut dengan deutochrysalis. Telur tungau berbentuk bulat, berwarna bening. Larva berwarna kehijauan dan bertungkai tiga pasang. Protonimfa mempunyai ukuran yang lebih besar dari larva, bertungkai empat pasang, dan berwarna kehijauan. Warna hijau lebih disebabkan oleh warna hijau daun yang tergambar pada tubuh yang transparan. Deutonimfa berwarna kemerahan dengan ukuran yang lebih besar. Imago betina berukuran sekitar $0,4 \mathrm{~mm}$ berbentuk bulat lonjong. Imago jantan berukuran lebih kecil dan ramping, dengan bentuk abdomen meruncing pada ujungnya. 
Lama beberapa stadia pradewasa dipengaruhi oleh kultivar jarak pagar yang menjadi makanannya (Tabel 1), tetapi total lama siklus hidup pradewasa tungau merah (sejak telur hingga terbentuk imago) tidak dipengaruhi oleh kultivar jarak pagar yang digunakan. Total siklus hidup tungau merah ini adalah 10,12 \pm 0,93 hari pada IP1-P dan $10.05 \pm$ 1,02 hari pada IP2-P .

Beberapa parameter hayati sangat dipengaruhi oleh kultivar jarak pagar yang digunakan (Tabel 2). Masa oviposisi tungau merah yang dipelihara pada kultivar IP1-P lebih panjang dibandingkan dengan IP2-P, yaitu 7,00 $\pm 2,37$ hari berbanding $5,00 \pm 2,71$ hari. Keperidian tungau merah pada IP1-P juga lebih tinggi dibandingkan dengan IP2-P, yaitu 25,56 $\pm 8,61$ telur berbanding 10,00 $\pm 7,06$ telur. Nisbah kelamin $($ ( $/$ ठ $)$ pada IP1-P lebih tinggi dibandingkan dengan IP2-P.

Nilai laju reproduksi bersih $\left(\mathrm{R}_{\mathrm{o}}\right)$ pada IP1-P $(6,1490)$ lebih tinggi dibandingkan dengan IP2-P $(2,4370)$. Laju pertumbuhan intrinsik tungau merah pada IP1-P dan IP2-P adalah 0,112 dan
0,0529 betina per induk per hari, yang bisa diartikan bahwa perkembangan populasi tungau merah pada IP1-P dua kali lipat dari IP2-P. Laju pertumbuhan terbatas pada IP1-P = 1,118 dan IP2-P $=1,054$. Rata-rata lama generasi $(\mathrm{T})$ adalah waktu yang dibutuhkan sejak telur diletakkan hingga saat betina menghasilkan keturunanya pada IP1-P dan IP2-P selama 16,2169 hari dan 16,8392 hari; waktu penggandaan (Dt) IP1-P dan IP2-P selama 6,1888 hari dan 13,1029 hari (Tabel 3).

\section{Kelimpahan tungau merah dan tungau predator pada pertanaman jarak pagar kultivar IP1-P dan IP2-P}

Tungau merah lebih banyak ditemukan pada daun sedang dan tua dibandingkan dengan pucuk (Gambar 1 dan 2). Populasi tungau merah pada pertanaman jarak pagar berfluktuasi sepanjang tahun. Secara umum populasi tertinggi terjadi pada bulan Agustus, sedangkan tingkat populasi terendah terjadi pada bulan Oktober-November. Pada musim penghujan, yang dimulai bulan

Tabel 1. Perkembangan pradewasa tungau merah Tetranychus sp. pada tanaman jarak pagar kultivar IP1 dan IP2

\begin{tabular}{|c|c|c|c|c|c|c|c|}
\hline \multirow{2}{*}{$\begin{array}{l}\text { Masa perkembangan } \\
\text { (hari) }\end{array}$} & \multicolumn{2}{|c|}{ IP1 } & \multicolumn{5}{|c|}{ IP2 } \\
\hline & $\mathrm{x} \pm \mathrm{SD}$ & $\mathrm{N}$ & $\mathrm{x} \pm \mathrm{SD}$ & $\mathrm{n}$ & $\mathrm{t}$ & $\mathrm{db}$ & $\mathrm{P}$ \\
\hline Telur & $3,18 \pm 0,23$ & 45 & $3,26 \pm 24$ & 33 & 1,52 & 76 & 0,06 \\
\hline Larva & $2,28 \pm 0,54$ & 30 & $1,91 \pm 1,12$ & 24 & 1,84 & 52 & 0,03 \\
\hline Protokrisalis & $0,77 \pm 0,15$ & 28 & $0,71 \pm 0,12$ & 20 & 1,35 & 46 & 0,09 \\
\hline Protonimfa & $1,27 \pm 0,37$ & 24 & $1,80 \pm 0,66$ & 16 & 3,23 & 38 & $<0,01$ \\
\hline Deutokrisalis & $0,72 \pm 0,20$ & 23 & $0.69 \pm 21$ & 16 & 1,62 & 37 & 0,06 \\
\hline Deutonimfa & $1,20 \pm 0,42$ & 21 & $1,29 \pm 0,50$ & 14 & 0,53 & 33 & 0,29 \\
\hline Teliokrisalis & $0,79 \pm 0,14$ & 21 & $0,88 \pm 0,13$ & 14 & 1,87 & 33 & 0,03 \\
\hline Total pradewasa & $10,12 \pm 0,93$ & 16 & $10,05 \pm 1,02$ & 14 & 0,19 & 33 & 0,42 \\
\hline
\end{tabular}

Tabel 2. Sifat biologi imago tungau merah Tetranychus sp. pada tanaman jarak pagar kultivar IP1 dan IP2

\begin{tabular}{|c|c|c|c|c|c|c|c|}
\hline \multirow{2}{*}{$\begin{array}{l}\text { Lama } \\
\text { perkembangan }\end{array}$} & \multicolumn{2}{|c|}{ IP1 } & \multicolumn{5}{|c|}{ IP2 } \\
\hline & $\mathrm{x} \pm \mathrm{SD}$ & $\mathrm{N}$ & $\mathrm{x} \pm \mathrm{SD}$ & $\mathrm{n}$ & $\mathrm{t}$ & $\mathrm{db}$ & $\mathrm{P}$ \\
\hline Praoviposisi & $1,16 \pm 0,38$ & 16 & $1,48 \pm 0,57$ & 10 & 1,72 & 24 & 0,05 \\
\hline Oviposisisi & $7,00 \pm 2,37$ & 16 & $5,00 \pm 2,71$ & 10 & 1,98 & 24 & 0,03 \\
\hline Pascaoviposisi & $3,50 \pm 2,48$ & 16 & $4,40 \pm 3,47$ & 10 & 0,77 & 24 & 0,22 \\
\hline Lama jantan & $9,40 \pm 1,82$ & 5 & $8,25 \pm 1,50$ & 4 & 1,01 & 7 & 0,17 \\
\hline Lama betina & $11,66 \pm 3,31$ & 16 & $10,88 \pm 3,66$ & 10 & 0,56 & 24 & 0,29 \\
\hline Keperidian & $25,56 \pm 8,61$ & 16 & $10,00 \pm 7,06$ & 10 & 3,29 & 24 & 0,001 \\
\hline Nisbah & & & & & & & \\
\hline kelamin $(† / ふ)$ & $3,2: 1$ & 16 & $2,5: 1$ & 10 & & & \\
\hline
\end{tabular}

Tabel 3. Parameter neraca hayati tungau merah Tetranychus sp. pada jarak pagar kultivar IP1 dan IP2

\begin{tabular}{lclcrrr}
\hline Kultivar & GRR & \multicolumn{1}{c}{$\mathrm{R}_{\mathrm{o}}$} & $\mathrm{R}$ & $\mathrm{T}$ & $\mathrm{Dt}$ & $\lambda$ \\
\hline IP1 & 16,0312 & 6,1490 & 0,112 & 16,2169 & 6,1888 & 1,1185 \\
IP2 & 8,236 & 2,437075 & 0,0529 & 16,8392 & 13,1029 & 1,0543 \\
\hline
\end{tabular}




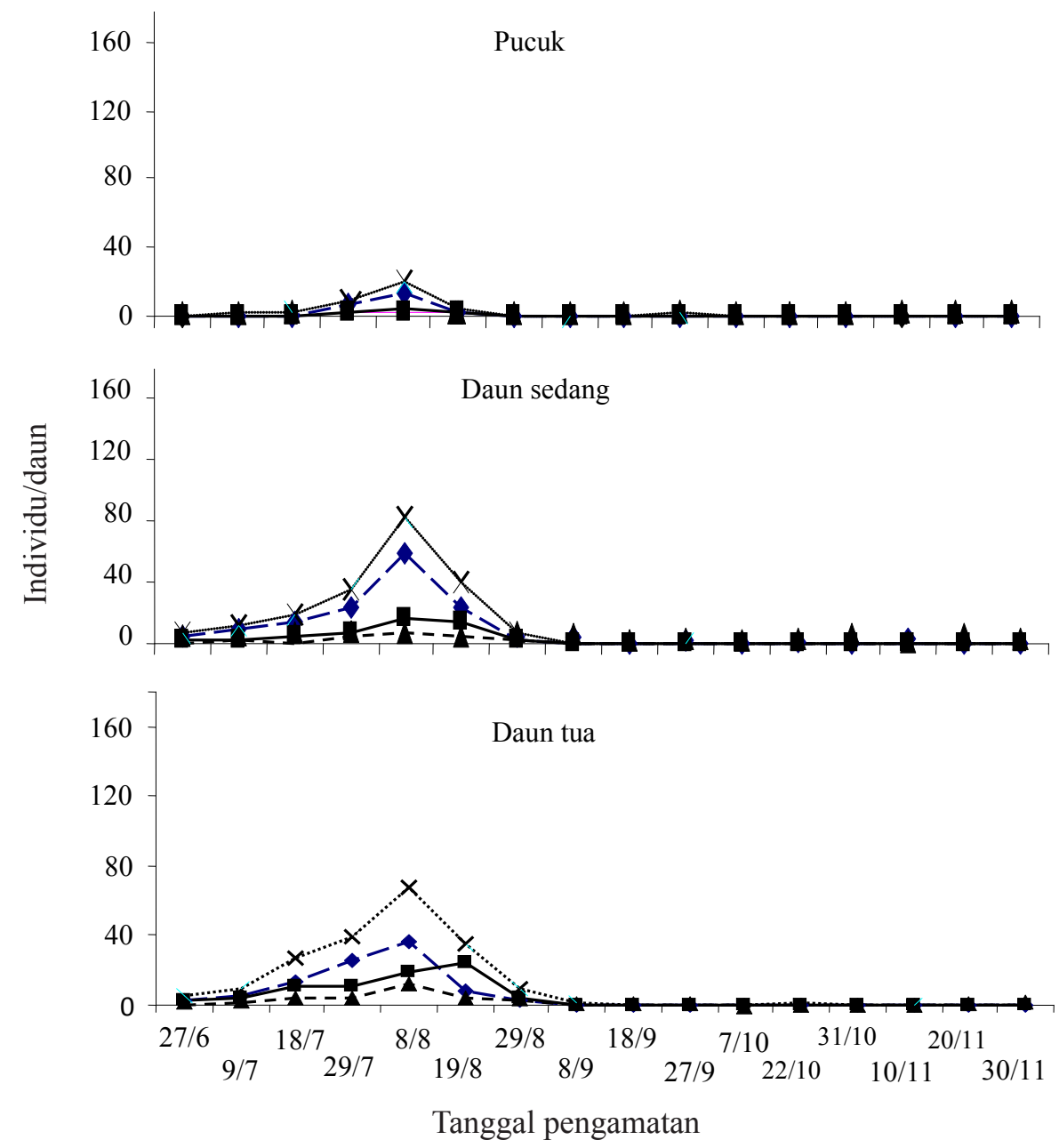

Gambar 1. Kelimpahan populasi tungau merah Tetranychus sp. pada dua kultivar jarak pagar IP1-P di

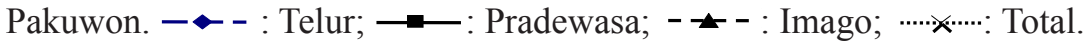

Tabel 4. Nilai korelasi antara kelimpahan tungau merah Tetranychus sp. dan tungau predator Famili Phytoseiidae

\begin{tabular}{llll}
\hline Varietas & $\begin{array}{c}\text { Bagian } \\
\text { Tanaman }\end{array}$ & $\mathrm{R}$ & $\mathrm{P}$ \\
\hline IP1 & Pucuk & $-0,182$ & 0,499 \\
& Muda & $-0,212$ & 0,43 \\
& Tua & $-0,382$ & 0,144 \\
IP2 & Pucuk & $-0,061$ & 0,824 \\
& Muda & 0,182 & 0,472 \\
& Tua & $-0,170$ & 0,572 \\
\hline
\end{tabular}

September, populasi tungau menjadi sangat rendah karena pengaruh mekanis dari curah hujan (Gambar 1 dan 2). Berdasarkan analisis ragam pengukuran berulang, kelimpahan populasi tungau merah pada kultivar IP2-P secara nyata lebih tinggi dibandingkan dengan IP1-P $\left(\mathrm{F}_{1,98}=22,87 ; \mathrm{P}\right.$ $<0,001)$.

Tungau predator Famili Phytoseiidae ditemukan pada semua umur daun, tetapi cenderung lebih tinggi pada daun sedang dan tua dibandingkan 38 dengan pucuk (Gambar 3). Populasi predator pada IP1-P dan IP2-P sangat rendah, rata-rata kurang dari satu ekor per daun. Beberapa jenis predator, yaitu Stethorus, Scolotrips, Coccinellidae, dan laba-laba juga ditemukan pada pertanaman jarak pagar. Phytoseiidae dapat mengatur populasi mangsa pada kerapatan yang rendah sehingga bisa terus bertahan hidup pada populasi mangsa yang rendah. Dalam penelitian ini tidak terdapat korelasi antara populasi tungau merah dengan populasi tungau predator (Tabel 4).

\section{PEMBAHASAN}

Salah satu masalah utama dalam pengembangan jarak pagar di Indonesia adalah serangan tungau. Ada tiga famili tungau yang diketahui menyerang jarak pagar, yaitu Eriophyidae, Tarsonemidae dan Tetranychidae. Tungau Famili Tarsonemidae banyak menyerang daun pucuk, Eriophyidae 


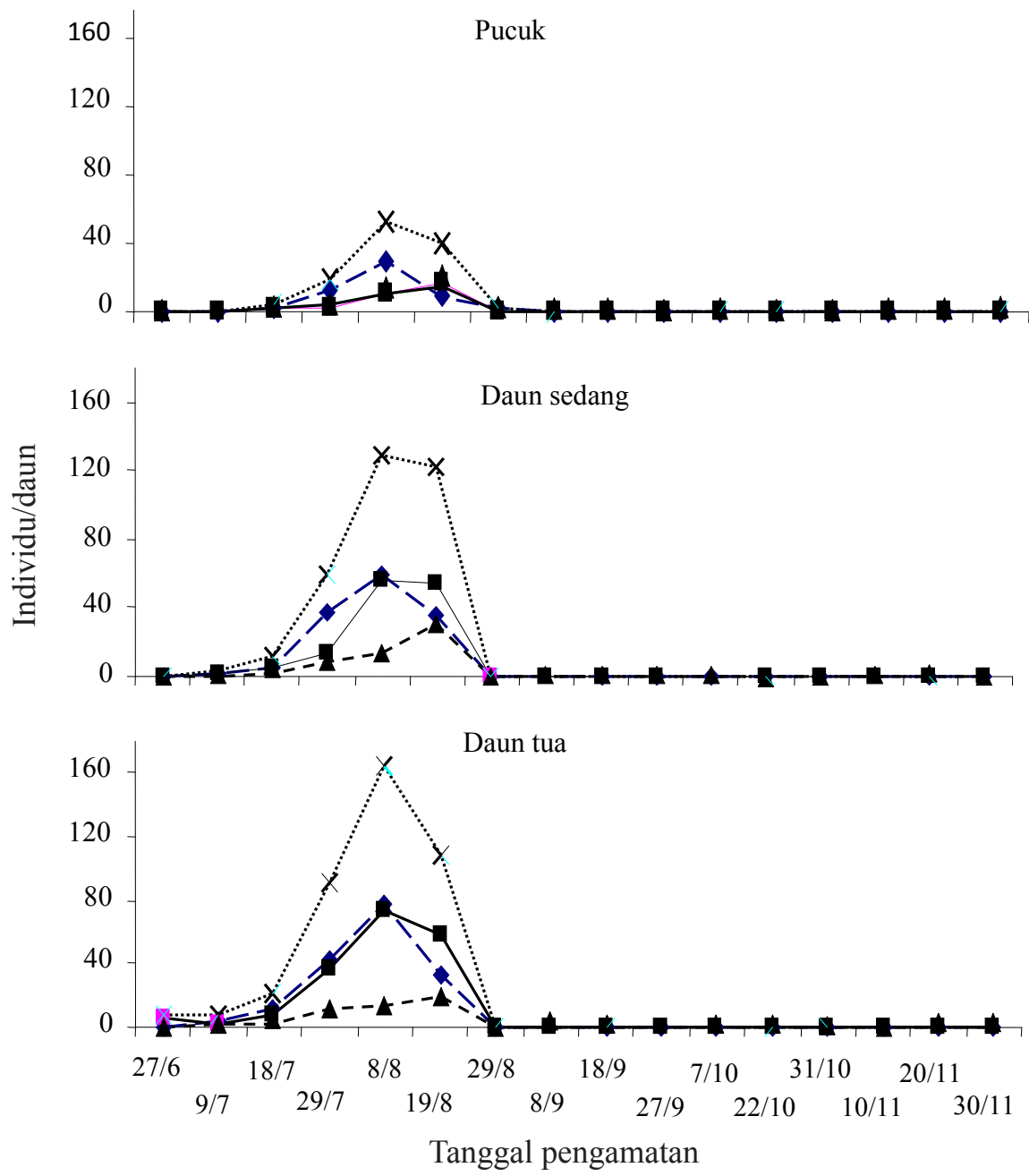

Gambar 2. Kelimpahan populasi tungau merah Tetranychus sp. pada dua kultivarjarak pagar IP2-Pdi Pakuwon. $\longrightarrow$-: Telur; ——: Pradewasa; - $₫-$ : Imago; ………: Total.

menyerang daun muda, sedangkan Tetranychidae banyak menyerang daun sedang dan tua.

Beberapa parameter neraca hayati Tetranychus sp. sangat dipengaruhi oleh kultivar jarak pagar yang digunakan, di antaranya masa oviposisi, keperidian dan proporsi betina. Namun demikian, beberapa parameter lain, seperti lama hidup betina dan masa praoviposisi tidak dipengaruhi oleh kultivar jarak pagar yang digunakan. Cone (1985) menyatakan bahwa masa praoviposisi tungau merah adalah satu hari pada suhu $24-29{ }^{\circ} \mathrm{C}$ Peningkatan suhu dapat mendorong peningkatan laju oviposisi (Zhang 2003). Lama masa oviposisi tungau merah pada kultivar IP1-P $(7,00 \pm 2,37$ hari) lebih lama dibandingkan dengan IP2-P (5,00 $\pm 2,71$ hari). Zhang (2003) menyatakan bahwa periode oviposisi tungau merah adalah sekitar 10 hari. Masa pascaoviposisi pada IP1-P 3,50 $\pm 2,48$ hari, tidak berbeda nyata dengan pada IP2-P (4,40 $\pm 3,47$ hari).
Kultivar jarak pagar juga mempengaruhi beberapa parameter neraca hayati tungau merah, yaitu laju reproduksi kotor, laju reproduksi bersih, dan laju pertumbuhan intrinsik. Nilai laju reproduksi bersih $\left(\mathrm{R}_{\mathrm{o}}\right)$ pada IP1-P $(6,1490)$ lebih tinggi dibandingkan dengan IP2-P $(2,4370)$, yang berarti jumlah keturunan betina pada IP1-P lebih banyak yang menjadi imago dibandingkan dengan IP2-P. Hasil penelitian juga menunjukkan bahwa laju pertumbuhan intrinsik tungau merah pada IP1-P dan IP2-P adalah 0,112 dan 0,0529 betina per induk per hari, yang bisa diartikan bahwa perkembangan populasi tungau merah pada IP1-P dua kali lipat dari IP2-P.

Laju pertumbuhan terbatas pada IP1-P = 1,118 dan IP2-P $=1,054$. Rata-rata lama generasi (T) adalah waktu yang dibutuhkan sejak telur diletakkan hingga saat betina menghasilkan keturunanya pada IP1-P dan IP2-P selama 16,2169 hari dan 16,8392 hari; waktu penggandaan (Dt) 


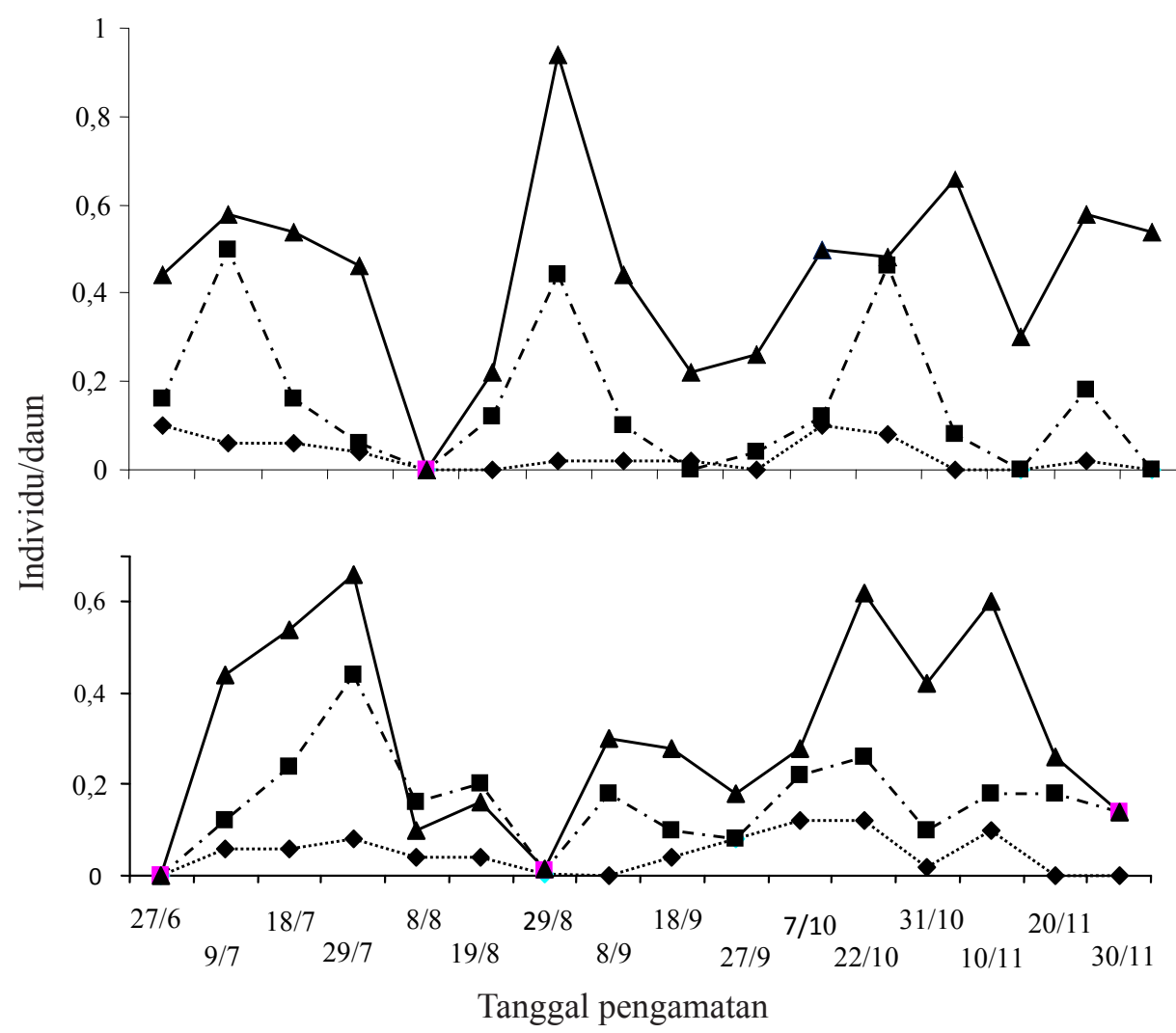

Gambar 3. Kelimpahan populasi tungau predator Famili Phytoseiidae pada kultivar IP1-P (atas) dan IP2-P (bawah). $\bullet-$ : Pucuk; - - : Sedang; $\neg$ : Tua.

IP1-P dan IP2-P selama 6,1888 hari dan 13,1029 hari. Laju intrinsik (r) adalah laju pertumbuhan populasi pada keadaan lingkungan konstan, sumberdaya tidak terbatas serta kematian yang terjadi hanya disebabkan oleh faktor fisiologi (Birch 1948).

Di lapangan populasi tungau merah lebih banyak ditemukan pada daun sedang dan tua dibandingkan dengan pada pucuk. Hal ini disebabkan oleh tungau merah lebih menyukai daun sedang dan tua, dan biasanya pada permukaan bawah daun (Sonneveld et al. 1996). Reddall et al. (2004) dari hasil penelitiannya menyatakan bahwa tungau merah lebih menyukai bagian dasar daun daripada ujung daun. Huffaker et al. (1969) menyatakan bahwa tungau merah lebih menyukai daun tanaman yang lebih tua karena memiliki jaringan tanaman yang mencukupi kandungan nutrisi yang dibutuhkannya.

Hasil pengamatan di lapangan menunjukkan bahwa populasi tungau merah berfluktuasi sepanjang tahun. Secara umum populasi tertinggi terjadi pada bulan Agustus yang sangat kering, sedangkan tingkat populasi terendah terjadi pada bulan Oktober-November yang sangat basah.
Rendahnya populasi tungau merah pada musim penghujan diduga karena pengaruh mekanis dari curah hujan. Berdasarkan analisis ragam pengukuran berulang, kelimpahan populasi tungau merah pada kultivar IP2-P secara nyata lebih tinggi dibandingkan dengan IP1-P $\left(\mathrm{F}_{1,98}=\right.$ 22,87; $\mathrm{P}<0.001)$. Lebih berlimpahnya populasi tungau merah pada IP2-P dibandingkan dengan IP1-P tidak konsisten dengan hasil penelitian neraca hayati sebelumnya, yang laju pertambahan intrinsik (r) lebih tinggi pada IP1-P daripada IP2-P. Hal ini diduga terkait dengan adanya kompetisi dari artropoda lain. Selama penelitian berlangsung, selain famili Tetranychidae, ditemukan tungau fitofag lain seperti tungau kuning (Tarsonemidae), tungau koma (Eriophyidae), tungau golongan Acaridae. Selain bebagai jenis tungau tersebut, hasil pengamatan juga menemukan berbagai jenis serangga hama yang berasosiasi dengan tanaman jarak pagar, yaitu trips, kutu tempurung (Megapulvinaria maxima), kutu putih (Paracoccus marginatus), kutu daun, ulat api (Lepidoptera), juga serangga pemakan serasah seperti Collembola. Populasi serangga hama ini sangat tinggi pada IP1-P dibandingkan dengan IP2-P, sehingga 
mungkin mengganggu perkembangan populasi tungau merah.

Tungau predator Famili Phytoseiidae ditemukan pada semua umur daun, tetapi cenderung lebih tinggi pada daun sedang dan tua dibandingkan pucuk. Hal ini diduga karena tungau merah lebih banyak ditemukan pada daun sedang dan tua. Meskipun ditemukan sepanjang penelitian, dan populasinya berfluktuasi, namun rata-rata kerapatan predator per daun kurang dari satu ekor. Dari hasil pengamatan juga ditemukan beberapa jenis predator yaitu Stethorus, Scolotrips, Coccinellidae, dan laba-laba. Predator Phytoseiidae termasuk predator generalis sehingga selain memakan tungau merah juga memakan tungau fitofag yang lain, kutu, telur-telur trips. Phytoseiidae dapat mengatur populasi mangsa pada kerapatan yang rendah sehingga bisa terus bertahan hidup pada populasi mangsa yang rendah.

Tidak ada korelasi antara populasi populasi tungau predator dan populasi tungau merah di pertanaman jarak pagar. Hal ini diduga disebabkan oleh sifat predator Phytoseiidae yang generalis, sehingga populasinya tidak hanya tergantung pada populasi satu jenis mangsa. Selain itu, ditemukannya beberapa jenis serangga predator tungau diduga mempengaruhi hal ini. Hagen et al. (1999) menyatakan bahwa Famili Phytoseiidae mendapat perhatian dan banyak diteliti. Cukup banyak spesies yang dimanfaatkan dalam pengendalian tungau dan serangga pada berbagai komoditi di berbagai negara. Spesies Phytoseiulus persimilis mampu mengonsumsi 10-12 telur tungau merah selama stadia nimfa, dan 14-22 telur per hari per betina yang sudah bertelur. Kelebihan dari karakteristik tungau predator ini adalah karena dapat berkembang pada kerapatan mangsa yang rendah, siklus hidup pendek, menghasilkan tanggap yang baik terhadap kenaikan populasi mangsa, bahkan jika jumlah mangsa relatif rendah (van de Vrie et al. 1972; Hagen et al. 1999).

\section{KESIMPULAN}

Kultivar IP1-P lebih sesuai bagi perkembangan tungau merah yang ditunjukkan oleh nilai laju pertambahan intrinsik (r) yang lebih tinggi. Kelimpahan populasi tungau merah lebih tinggi pada kultivar IP2-P dibandingkan dengan IP1-P, terutama sepanjang akhir bulan Juli hingga akhir Agustus. Tungau predator famili Phytoseiidae ditemukan berasosiasi dengan tungau merah, tetapi kurang memiliki peran sebagai pengendali alamiah.

\section{UCAPAN TERIMA KASIH}

Ucapan terima kasih disampaikan kepada Badan Penelitian dan Pengembangan Pertanian, Kementerian Pertanian yang sudah mendanai penelitian ini melalui Hibah KKP3T.

\section{DAFTAR PUSTAKA}

Asbani N, Amir AM, Subiyakto. 2007. Inventarisasi hama tanaman jarak pagar Jatropha curcas L. Di dalam: Prosiding Lokakarya II: Status Teknologi Tanaman Jarak Pagar Jatropha curcas L. (Bogor, 29 November 2006). pp. 83-90. Bogor: Pusat Penelitian dan Pengembangan Perkebunan.

Birch LC. 1948. The intrinsic rate of natural increase of an insect population. Journal of Animal Ecology 17:15-26.

Cone WW. 1985. Mating and chemical communication. In : Helle W, Sabelis MW, (Eds.). Spider Mites Their Biology, Natural Enemies, and Control. Vol 1A. pp: 243-251. Tokyo: Elsevier.

Deciyanto S, Amir M, Trisawa IM, Harijanto S. 1989. Studi biologi dan perkembangan hama tungau Tetranychus sp. (Tetranychidae: Acarina) pada tanaman mentha. Jurnal Penelitian dan Pengembangan Tanaman Industri 15:9-14.

Deciyanto S, Trisawa IM, Adriani RR. 1991. Studi beberapa inang hama tungau (Tetranychus sp.) asal tanaman Mentha sp. Jurnal Penelitian dan Pengembangan Tanaman Industri 17:48-55.

Hagen KS, Mills NJ, Gordh G, McMurty JA. 1999. Terresterial arthropod predators of insects and mites pests. In: Bellows TS, Fisher TW, (Eds.). Handbook of Biologycal Control. Principles and Applications of Biologycal Control. pp 383-503. Sydney: Academis Press.

Hambali E, Suryani A, Dadang, Hariyadi, Hanafie H, Imam KR, Rivai M, Ihsanur M, Suryadarma P, Tjitrosemito S, Soerawidjaja TH, Prawitasari T, Prakoso T, Purnama W. 2006. Jarak Pagar Tanaman Penghasil Biodisel. Jakarta: Penebar Swadaya. 
Hamdi A. 2007. Implementasi Kebijakan Pengembangan Jarak Pagar Sebagai Sumber BBN. Di dalam: Prosiding Lokakarya II Status Teknologi Tanaman Jarak Pagar Jatropha curcas L. (Bogor, 29 Nopember 2006). pp. 1-16. Bogor: Pusat Penelitian dan Pengembangan Perkebunan.

Huffaker CB, Van de vrie M, McMurtry JA. 1969. The ecology of tetranychid mites and their natural control. Annual Review of Entomology 14:125174. doi: http://dx.doi.org/10.1146/annurev.en. 14.010169.001013.

Karmawati E. 2006. Jarak pagar (Jatropha curcas). Available at: http://www.perkebunan.litbang. deptan.go.id [acessed 1 April 2008].

Prihandana R, Hambali E, Mujdalipah S, Hendroko R. 2007. Meraup Untung dari Jarak Pagar. Jakarta: PT Agro Media Pustaka.

Reddal A, Sadras VO, Wilson LJ, Gregg PC 2004. Physiological responses of cotton to two spotted spider mite damage. Crop Science 44:835-846. doi: http://dx.doi.org/10.2135/cropsci2004.0835.

Rumini W, Karmawati E. 2007. Hama Pada Tanaman Jarak Pagar. Di dalam: Prosiding Lokakarya II Status Teknologi Tanaman Jarak Pagar Jatropha curcas L. (Bogor, 29 Nopember 2006). Bogor: Pusat Penelitian dan Pengembangan Perkebunan. Sonneveld T, Wainwraight H, Labuschagne L. 1996. Development of two spotted spider mite on strawberry and rasphberry cultivars. Annals of Applied Biology 129:405-413. doi: http://dx.doi. org/10.1111/j.1744-7348.1996.tb05764.x.

Vrie M van de, McMurtry JA, Huffaker CB.1972. Biology, ecology, and pests status and host-plant relations of tetranychids. Hilgardia 41:343-432.

Zhang ZQ. 2003. Mites of Greenhouses, Identification, Biology and Control. Cambridge: CABI Publishing. doi: http://dx.doi.org/10.1079/ 9780851995908.0000. 